\title{
BIRDS
}

\section{SUMMER TANAGER AT VALEPORT}

\section{FERNE LAWRENCE, 405-2301 Lorne Street, Regina, SK S4P 2N1}

The Ducks Unlimited field trip to Valeport 27 May 1997 was not leaving the Royal Saskatchewan Museum parking lot until 7:30 pm. Lucy Eley and I, who had believed we were to meet at 7:00 pm, decided to leave earlier. On arrival at Valeport we saw Burt and Lois Gibson, who told us they had seen a different bird. They described it as much larger than a warbler with an orange-yellow breast and large beak which was darker on top and lighter below. Where they viewed it the illumination would have been behind them and on the bird. It was near the top of a tree about 30 feet up the path that borders the water.

Lucy and I walked what we believed would be a distance of 30 feet or more without seeing anything unusual. Since someone was fishing ahead of us, we cut through the trees to the picnic area. There with binoculars we watched for any signs of bird activity in the trees. We noticed a bird, similar in colour to the female Northern (Baltimore) Oriole, but mostly hidden by foliage. As more of the bird appeared, it had a very orangish breast without the sheen of an oriole; he beak was longer than a grosbeak and rather thick. When it fanned out its ail a little, the tail looked to be a light usty brown. We were not aware of any wingbars. Lucy recalls it as having a ather uniform appearance and that the peak was dark, but not real dark. (Some of the darkness might be attributed to he time of day and that we were facing west.)

When we had our best view of the bird, the rest of the group drove in. With Lucy keeping track of the bird, I went to ask them to come and help in identification. Just as we returned, the bird flew into a nearby willow, but must have gone farther as we could not locate it there. That night we believed it was probably a tanager that we four had seen.

The Golden Guide,"Birds of North America", states that the female Summer Tanager is orange-yellow; Peterson's "Eastern Field Guide" describes the female being much the colour of the female oriole with the underparts more orange than the female Scarlet Tanager. On checking their Golden and National Geographic field guides, Burt and Lois Gibson saw that the shape of the bird had the dark shading above the beak of the female Summer Tanager were like those of the bird they had viewed. We now conclude it was a female Summer Tanager we had seen.

Though bird guides have shown the Summer Tanager with a light yellow beak, an article by William J. Walley, Dauphin, Manitoba (Blue Jay 51:47, 1993) describes a first-year male, whose beak was grey with light yellowish edges.

The "Audubon Society Master Guide to Birding" by John Farrand Jr., Third Volume, mentions that the beak of both sexes of the Summer Tanager is pale in breeding plumage and darker at other times of the year. This bird could have been in transition plumage and not yet in breeding plumage. 
The "Atlas of Saskatchewan Birds" by Alan R. Smith, 1996, lists previous Saskatchewan sightings of the Summer Tanager, all in the spring, at Frontier, 7th May 1976; Canora, 11th or 12th May 1993; and Regina, 13-16 May 1993.

The Regina sighting in May 1993 of an immature male Summer Tanager was viewed by many birders and also photographed. I saw it 14 May on the north side of Wascana Lake, and also on 15 May on the south side of the lake, the day of the Regina Spring Bird Count.

When talking to Bob Luterbach about the sighting at Valeport, he asked that I record it for the Blue Jay. I would like to thank him for providing information from the "Audubon Society Master Guide to Birding" and his related comment. would also like to thank Fred Lahrman for the information from the "Atlas of Saskatchewan Birds".

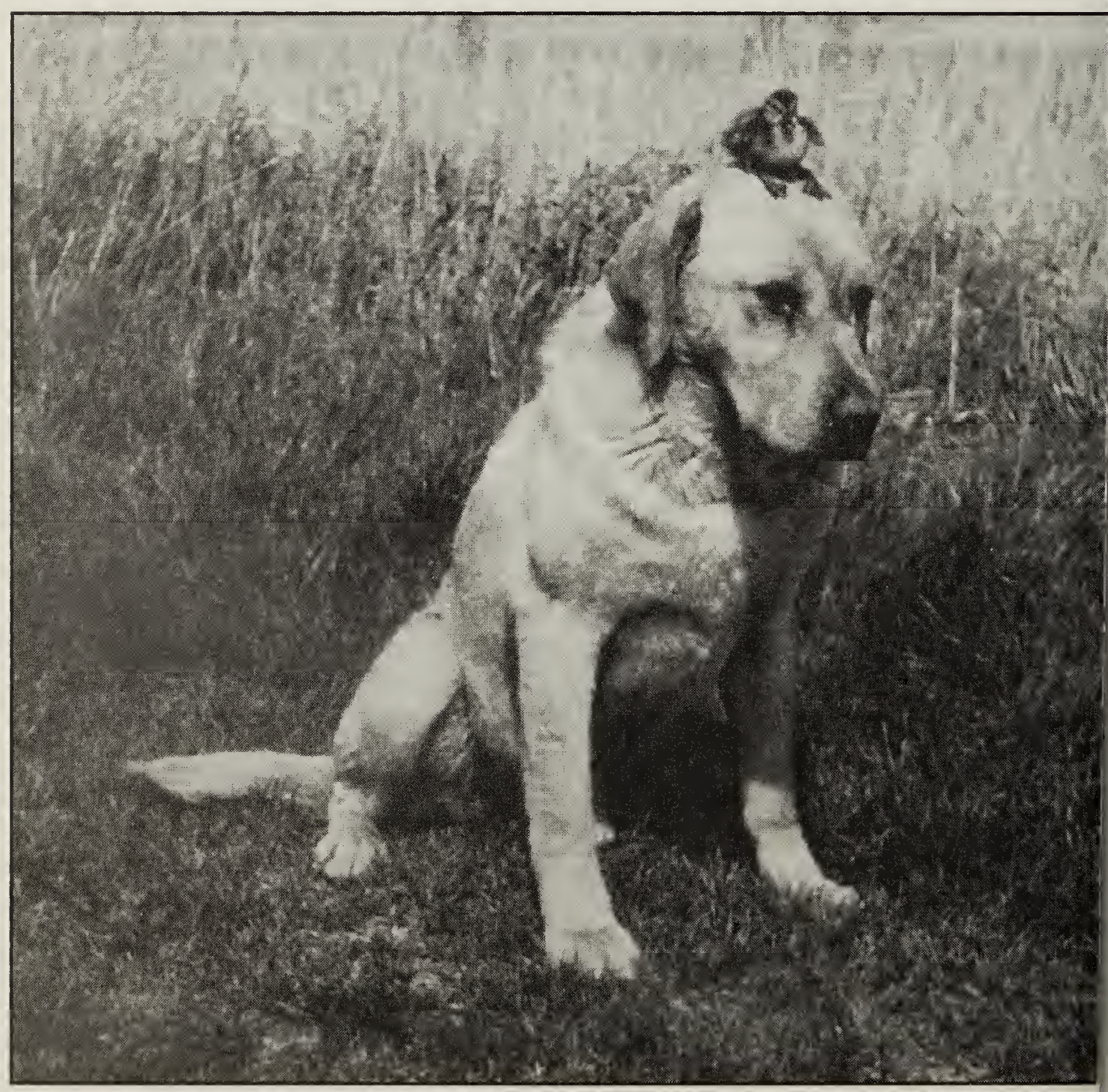

Young Mallard on Labrador (dog) 